\title{
Urbanization alters the abundance and composition of predator communities and leads to aphid outbreaks on urban trees
}

\author{
Dávid Korányi ${ }^{1,2,3}$ (D) $\cdot$ Viktor Szigeti $^{4} \cdot$ László Mezőfi $^{5} \cdot$ Elöd Kondorosy $^{1} \cdot$ Viktor Markó $^{5}$
}

Accepted: 20 September 2020 / Published online: 3 October 2020

(C) The Author(s) 2020

\begin{abstract}
Urbanization can affect arthropod abundance in different ways. While species with narrow habitat range and low dispersal ability often respond negatively to urban environments, many habitat generalist species with good dispersal ability reach high densities in city centers. This filtering effect of urban habitats can strongly influence predator-prey-mutualist interactions and may therefore affect the abundance of predatory and phytophagous species both directly and indirectly. Here, we assessed the effect of urbanization on aphids, predatory arthropods, and ants on field maple (Acer campestre) trees in and around the city of Budapest, Hungary. We used the percentage of impervious surfaces within a $500 \mathrm{~m}$ radius of each site as an index of the degree of urbanization. We found that the abundance of aphids increased with increasing level of urbanization. However, abundance of predatory arthropods and occurrence of poorly dispersing species within the predator community were negatively related to urbanization, and we identified these two independent factors as significant predictors of aphid abundances. The abundance of ants decreased with urbanization, and contrary to our expectations, did not affect the abundance pattern of aphids. Our results suggest that urbanization, by altering the abundance and composition of predator communities, can disrupt biological control of aphid populations, and thus may contribute to the aphid outbreaks on urban trees.
\end{abstract}

Keywords Urban landscape $\cdot$ Predator-prey interactions $\cdot$ Pest control services $\cdot$ Community composition $\cdot$ Dispersal ability

\section{Introduction}

The number of people living in cities continues to grow, and the expansion of urban land cover is predicted to increase by 1.2

Electronic supplementary material The online version of this article (https://doi.org/10.1007/s11252-020-01061-8) contains supplementary material, which is available to authorized users.

Dávid Korányi

koranyi.david@okologia.mta.hu

1 Department of Animal Science, University of Pannonia, Deák Ferenc utca 16, Keszthely H-8361, Hungary

2 Centre for Ecological Research, Institute of Ecology and Botany, "Lendület" Landscape and Conservation Ecology, Alkotmány út 24, Vácrátót H-2163, Hungary

3 Centre for Ecological Research, GINOP Sustainable Ecosystems Group, Klebelsberg Kuno utca 3, Tihany H-8237, Hungary

4 Centre for Ecological Research, Institute of Ecology and Botany, "Lendület" Ecosystem Services Research Group, Alkotmány út 2-4, Vácrátót H-2163, Hungary

5 Plant Protection Institute, Szent István University, Ménesi út 44, Budapest H-1118, Hungary million $\mathrm{km}^{2}$ by 2030 (Seto et al. 2012). As a result, a landscape with heterogeneous elements, from semi-natural remnant forests and public green areas to concrete surfaces and artificial structures is created, which has a wide range of functional characteristics and environmental conditions. This landscape provides an opportunity for studying complex ecological systems operating under strong human influence (Alberti 1999; McDonnell and Hahs 2008; McDonnell and Pickett 1990).

Although the number of studies examining the effects of urban landscapes on ecological patterns and processes has increased considerably in the past years, fewer studies have focused on arthropods compared to other taxa (Muderere et al. 2018). Arthropods are an ideal choice for studying the effects of urbanization as they (1) show quick responses to changed conditions, (2) have great biological diversity, (3) have relatively short generation time, and (4) represent a broad spectrum of trophic levels (McIntyre 2000). Arthropods show various responses to increasing levels of urbanization. While species that are less mobile or habitat specialist decrease in abundance or disappear altogether with increased urbanization, species that are highly mobile, or habitat generalists can reach high densities (Comont et al. 2014; McIntyre 2000; Niemelä and Kotze 2009). This process can lead to biotic 
homogenization (McKinney 2006). Urbanization can also influence the abundance (Corcos et al. 2019; Denys and Schmidt 1998; Rocha and Fellowes 2020) and composition (Argañaraz et al. 2018; Burkman and Gardiner 2014; Lövei et al. 2019) of species at higher trophic levels, which might affect the top-down control of some herbivorous species, such as sap-sucking insects, and result in outbreaks of their populations (Meineke et al. 2017; Raupp et al. 2010; Shrewsbury and Raupp 2006).

Within the sap sucking insects, aphids (Hemiptera, Aphididae) are important worldwide pests of more than 400 plant species, including agricultural crops and ornamental plants (Blackman and Eastop 2000). They are also appropriate model organisms for studying how urbanization might affect predator-prey-mutualist systems because they (1) can reach high densities in urban areas (Denys and Schmidt 1998; Honěk et al. 2018; Parsons and Frank 2019), (2) have a wide range of natural enemies (Nagy et al. 2015), and (3) often have a mutualistic relationship with ants (Dixon 1998).

Aphidophagous arthropods have a strong tendency to aggregate on aphid colonies, and they can play a key role in setting the density of aphid populations (Dixon 1998; Markó et al. 2013; Piñol et al. 2009b; Roy et al. 2016). However, the level of predation pressure on aphids depends on several factors including the spatial and temporal distribution of aphids, their natural enemies, and mutualistic ants. Predatory arthropods can be more detrimental to aphids at the beginning of aphid population development when colonies are small, and the per capita predation risk is high (Boreau de Roincé et al. 2013; Gómez-Marco et al. 2016; Nagy et al. 2015). Highly mobile predators usually arrive in greater numbers when aphid colonies are already large, and are therefore often tracking rather than driving their abundance, while more sedentary predators that have a lower dispersal ability and higher degree of habitat fidelity might stay at the sites even when aphid density is low, and can thus suppress the aphid population increase more effectively (Markó et al. 2013; Piñol et al. 2009b; Welch and Harwood 2014).

Aphid abundance can also be affected by the presence of ants, which can act as mutualists by protecting aphid species that provide sugar-rich honeydew for them (Dixon 1998). Skinner and Whittaker (1981), for example, showed that the abundance of ant-tended species, such as Periphyllus testudinaceus (Fernie), increased in the presence of the ant Formica rufa L. on sycamore trees (Acer pseudoplatanus L.). Predators and ants might respond differently to urbanization, which could lead to different outcomes for aphid species. However, despite the importance of natural enemies in shaping herbivorous insect communities, only a few studies have investigated the effects of urbanization on predator-prey-mutualist systems (Eötvös et al. 2018; Rocha and Fellowes 2018, 2020).
Turrini et al. (2016) studied how the abundance of a nonant-tended (non-myrmecophilous) aphid species, the vetch aphid (Megoura viciae Buckton), changed on potted broad bean (Vicia faba L.) plants in agricultural versus urban ecosystems. They applied treatments with and without predator exclusion and found that aphid abundance was determined by predation, which was less intense in city centers than in agricultural fields. As a consequence, aphids showed a pattern opposite to predators, being more abundant in the city centers. In a similar study Rocha and Fellowes (2018) examined an ant-tended (myrmecophilous) aphid species, the black bean aphid (Aphis fabae Scopoli), on the same host plant and found that the presence of mutualist ant species (Myrmica rubra L. and Lasius niger L.) overrode the effect of predators and, therefore, aphid abundance showed no difference between highly-urbanized and semi-natural areas.

In this study, we examined the abundance pattern and interactions of aphids, predatory arthropods, and ants in the canopy of field maple (Acer campestre L.) trees along an urbanization gradient. We chose A. campestre because it is highly tolerant of urban conditions (Roloff et al. 2009) and common both in rural and urban habitats with a rather uniform distribution in Hungary (Bartha et al. 2018). Moreover, A. campestre is fed on by several aphid species, which are preyed on by a large number of predatory arthropods. More specifically, we tested the following hypotheses: along the urbanization gradient (1) the abundance of aphids, predators and ants would increase, decrease and not change, respectively; (2) considering the whole growing season, the predatory arthropods would affect negatively while ants, through their negative effect on predators, would affect positively the abundance of aphids; (3) during the peaks in aphid abundance, the populations of predatory arthropods and ants would track the abundance of aphids; (4) the composition of the predator community would change along the urban gradient. Finally, we also hypothesized (5) that a shift in predator community composition towards species with high dispersal ability would lead to higher aphid abundance.

\section{Methods}

\section{Study area and arthropod collection}

We selected 22 sites for this study in or near the city of Budapest, Hungary (Fig. S1), representing a range of seminatural rural, suburban, and urban areas. We chose three field maple (A. campestre) trees at each site for arthropod collection by having similar trunk and canopy diameters and the shortest distance between them. The distance between the trunks of the sampled trees was $2-15 \mathrm{~m}$. There was no significant effect of urbanization (defined as the proportion of impervious surfaces) on the trunk diameters (diameter at breast height) 
(Pearson $r=0.24, p=0.28$ ) and on the distance between the selected trees (Pearson $r=0.14, p=0.55$ ).

A beating funnel $70 \mathrm{~cm}$ in diameter, $60 \mathrm{~cm}$ in depth, together with a $120 \mathrm{~cm}$ long beating stick, was used to collect arthropods from the canopy of the trees (Basset et al. 1997). In order to standardize sampling effort, ten branches were sampled per tree. Branches were sampled monthly on seven dates in 2016 (April 26, May 25, June 22, July 18, August 15, September 13, and October 14). In 2017, we also sampled on three additional dates (May 5, July 16, and September 27). On all sample dates, we identified and counted all collected aphids (Aphididae) to species. Predatory arthropods (Hemiptera, Coccinellidae, Dermaptera, Neuroptera, and Araneae) were identified to species or, if not possible, to genus or family, using characters of the exoskeleton or genitalia. The collected arthropods were deposited at the Department of Entomology of Szent István University. Because of the low aphid parasitism rates observed, parasitoids were not included in this study.

\section{Dispersal ability of predators}

Aphidophagous predator species were classified into five dispersal groups following the methodology described by Gossner et al. (2015) using data of different literature sources (Bell et al. 2005; Blandenier 2009; Duffey 1956; Gossner et al. 2015; Wachmann et al. 2004-2012). We considered wing morphology for true bugs, ladybirds, and lacewings (always brachypterous, predominantly brachypterous, equally brachypterous and macropterous, predominantly macropterous, and always macropterous; coded 0.00, 0.25, 0.50, 0.75 and 1.00 respectively), and ballooning ability for spiders (nonballooning species [code: 0.00 ], species with weak ballooning propensity [code: 0.25 ], ballooning species observed outside the main habitat less frequently [code: 0.50 ] and frequently [0.75], and species with the highest ballooning propensity and dispersal distances [code: 1.00]). For juvenile spider individuals which were identified to genus or species group (e.g. Philodromus aureolus and rufus group) level, we used the dispersal trait values of adult individuals representing the same genus or species group weighted by their relative abundances. The collected dermapteran species were considered as species with the lowest dispersal category (code: 0.00) as Apterygida media (Hagenbach) and Chelidurella acanthopygia (Géné) are apterous species, and although Forficula auricularia L. has wings, it hardly ever uses them (Crumb et al. 1941) and the mobility of this species is very low (Moerkens et al. 2010). For the assigned dispersal trait values, see Table S1.

\section{Landscape structure}

We calculated landscape composition around each sampling site within a $500 \mathrm{~m}$ radius buffer with the OpenStreetMap land cover map, using OpenLayers plugin of Quantum GIS 2.16 software (Quantum GIS Development Team 2018). This radius has been found to be appropriate spatial scale for analyzing the relationship between landscape pattern and aphid-antpredator relationships (Schüepp et al. 2014; Stutz and Entling 2011). The geographic center (centroid) of a triangle formed by the sampled trees was used as the center of each study site. To characterize the landscape composition of the study sites, we considered six land cover types (buildings, roads, forests, gardens, meadows, and parks) and calculated their percentage cover in a buffer around each site (Table S2). We excluded water bodies from our analyses due to their low abundance within the sampled landscapes.

\section{Analyses}

First, to explore the correlations among the six landscape variables, we calculated the Kendall rank correlation coefficients for all pairs of the six land cover variables. We found significant correlations between most landscape variables (Table S3); therefore, we used only the proportion of impervious surfaces (pooled proportion of buildings and roads) as an explanatory variable in further analyses. Finally, a gradient was created from this variable among the sites that ranged between 2 and 95\% surface with impervious cover (Table S2) indicating the degree of urbanization. For all analyses, we pooled the number of individuals collected (from three trees) at each site. For analysis of annual abundance, we pooled data across sampling dates in both years and analyzed them separately. The spatial autocorrelation in the residuals of our models was tested by Moran's I tests with inverse distance weighting using 'spdep' package version 1.1-3 (Bivand and Wong 2018). There was no evidence of residual spatial autocorrelation in any model ( $p>0.21$ in all cases), and therefore we did not add an auto-covariate to our models. We used R 3.4.4 statistical environment (R Core Team 2018) for all analyses.

\section{Hypothesis 1: Effects of urbanization on the abun- dance patterns of aphids, predators and ants}

To test how annual and monthly abundance of aphids, predators, and ants (response variables) depended on the proportion of impervious surfaces (explanatory variable), we used Poisson-distributed generalized linear models (GLMs). The models included the percentage of impervious surfaces as a fixed factor. Because we detected overdispersion in the abundance data, we corrected the standard errors using generalized linear models with quasi-Poisson distribution (quasi-GLMs) (Zuur et al. 2009). In case of monthly analyses, $p$ values were adjusted using the method of Benjamini and Hochberg (1995). 
Hypotheses 2 and 3: Aphid-predator-ant interactions

Since the effects of predators and mutualistic ants on aphid population development might be accumulated and delayed, we tested how annual aphid abundance (response variable) depended on annual and monthly abundance of predators and ants (explanatory variables) using quasi-GLMs. We fitted the models separately for each sample year and month. The full models included predator and ant abundance as fixed factors, and model selection retained only the models with significant variables $(p<0.05)$. In the analyses, where monthly abundances of predators were considered as explanatory variables, $p$ values were adjusted with the Benjamini-Hochberg method. To determine whether there is any relationship between predator and ant abundances in each year, we built quasi-GLMs including the abundance of predators as response variable and the abundance of ants as explanatory variable (fixed factor).

We also tested how abundance of predators and ants was influenced by the abundance of aphids (tracking) in different years and seasons using generalized linear mixed effects models with quasi-Poisson errors (penalized quasi-likelihood GLMM, GLMMPQL) in the package 'MASS' version 7.351.4 (Venables and Ripley 2002). In order to obtain a meaningful quantitative response, only the months of peak aphid abundance were considered (April, May and October in 2016; May and September in 2017). In the model, the response variable was the abundance of predators or ants, and abundance of aphids, season, and year were entered as fixed factors. To control for the possible effect of sampling location on the response variables, we included sampling site as a random intercept factor.

\section{Hypothesis 1 and 4: Species of aphids and predators and taxonomic composition of predator community}

To analyze how the observed number of aphid or predatory species, the number of species groups, and genera (response variables) responded to the proportion of impervious surfaces (explanatory variable), we used quasi-GLMs. Only those arthropod groups (species, species groups, or genera) represented by at least 50 individuals in each year's samples were included in the analyses (for species groups and genera, see Table S4). In the case of Harmonia axyridis Pallas, juvenile and adult stages were analyzed separately. The full model included percentage of impervious surfaces as a fixed factor. The data from the two years (2016 and 2017) were analyzed separately. In these analyses, $p$ values were adjusted using the Benjamini-Hochberg method.

We performed non-metric multidimensional scaling (NMDS) to examine the differences in composition for the predator community and within the three largest predatory assemblages: true bugs (Heteroptera), aphidophagous ladybirds (Coccinellidae), and spiders (Araneae), each separately. We used the Bray-Curtis distance measure to compute the resemblance matrix among sites. The resulting matrix was the basis for creating a NMDS ordination, in which sites were ranked based on their similarity and then plotted in 2dimensional ordination space. The analyses were based on species-level abundance data. Because we collected samples in both years only in May, July, and September, the abundance data of these three months were pooled across years for the NMDS analyses of true bugs, aphidophagous ladybirds, and spiders. We generated smooth surfaces along impervious surface gradient with generalized additive models (GAMs). This function automatically selects the degree of smoothing by generalized cross-validation and interpolates the fitted values on the NMDS plot. NMDS was performed using 'metaMDS' function, while GAMs were run using 'odisurf' function of the package 'vegan' version 2.5-3 (Oksanen et al. 2018).

\section{Hypothesis 5: Effect of dispersal ability of predators on aphids}

We calculated community weighted means (CWM) for dispersal trait of predators using the averages of trait values weighted by the relative abundances of each predator species at each study site $(n=22)$ (Ricotta and Moretti 2011). We used the 'FD' package version 1.0-12 to calculate CWM indices (Laliberte and Legendre 2010). In case of some spider individuals, dispersal trait classification was not possible, due to the family level identification $(n=23)$ or the lack of adult representatives of the genus $(n=24)$ (Table S1), thus these individuals were excluded from the analyses. We used general linear models to test whether percentage of impervious surfaces (explanatory variable, fixed factor) had a significant effect on CWM of dispersal trait (response variable) in 2016 and 2017 separately.

Quasi-GLMs were used to assess whether predators with lower dispersal ability would have a more important role in aphid suppression than those with higher dispersal ability. The models included annual abundance of aphids as a response variable and CWM of dispersal ability of predator community as an explanatory variable (fixed factor) for each year.

Finally, predators were classified into eleven groups based on their taxonomic status and abundance: (1) Dermaptera, (2) Deraeocoris lutescens, (3) other heteropterans (all Heteroptera except $D$. lutescens), (4) H. axyridis larvae, (5) H. axyridis adults, (6) other coccinellids, (7) Neuroptera, (8) web building spiders, (9) the Philodromus aureolus group, (10) the Philodromus rufus group, and (11) other hunting spiders (for detailed data see Table S1). We used NMDS to analyze how these species and groups were associated to aphid abundance using 'metaMDS' function. For this analysis, we summed data for the two sample years for the abundance of aphids and for each predator species or group. We 
used Euclidean distance measure for comparing similarities and generated smooth surfaces along aphid infestation with GAMs using 'odisurf' function.

\section{Results}

\section{Taxa recorded}

In total, we collected 10,197 individual aphids (Sternorrhyncha, Aphididae), 8955 predators, and 3555 ants (Hymenoptera, Formicidae) from the canopy of A. campestre trees. The collected aphids belonged to four genera and nine species. Among these, two ant-tended species, Periphyllus testudinaceus and Periphyllus obscurus Mamontova, were collected in the largest numbers $(59.5 \%$ and $30.9 \%$ of total aphid abundance, respectively) followed by two non-anttended species, Drepanosiphum aceris Koch and Drepanosiphum platanoidis (Schrank), which occurred only in small numbers $(2.1 \%$ and $1.8 \%$ of the total aphid abundance, respectively). The most abundant ant species were Prenolepis nitens (Mayr), L. niger, and Lasius emarginatus (Olivier) $(32.7 \%, 21.6 \%$, and $10.4 \%$ of the ants collected, respectively). These ant species are known for honeydew utilization and having mutualistic relationships with aphids (Miñarro et al. 2010; Purkart et al. 2019), thus we assumed that they have mutualistic interactions with the myrmecophilous aphid species ( $90.5 \%$ of aphids collected).

The predators we collected comprised 24 families, 103 genera, and 145 species. They consisted mainly of spiders (Araneae; $32.4 \%$ ), coccinellids (28.2\%), mirid bugs (25.9\%), forficulid earwigs (9.3\%), and, to a lesser degree, lacewings (Neuroptera, Chrysopidae, and Hemerobiidae; 1.6\%), anthocorid flower bugs (1.6\%), and other species (1.3\%). The most abundant predator species were Deraeocoris lutescens (Schilling) (Miridae, $n=1450$ ), Harmonia axyridis (Coccinellidae, $n=1439$ ), Forficula auricularia (Forficulidae, $n=675$ ), and two species groups of spiders Philodromus aureolus group $(n=752)$ and Ph. rufus group $(n=692)$ (Philodromidae) (Tables S1 and S4).

\section{Effects of urbanization on the abundance of aphids, predators and ants}

Aphids were abundant in spring and autumn, while in summer they were almost absent. Predator abundance was lowest in spring and increased throughout the growing season. The monthly abundances of ants showed a less clear pattern. They were abundant in April and June in 2016 and in May and September in 2017 (Fig. 1). For the monthly abundances of each aphid species and predatory groups, see Fig. S2.

The annual abundance of aphids increased significantly with increase in the percentage of impervious surfaces in both years $(2016: p=0.008 ; 2017: p<0.001)$. In contrast, the abundance of predators and ants was negatively affected by the percentage of impervious surfaces, and these relationships were also significant for both groups $(p=0.039$ and 0.013 , respectively) in 2016 and nearly significant for ants $(p=$ 0.073 ) in 2017 (Table 1, Fig. 2).

The pattern of insects along the urbanization gradient also varied over time. Aphid abundance was positively affected by the percentage of impervious surfaces in spring and autumn, but not in May 2016, when this relationship was negative but not significant ( $p=0.054)$ (Figs. 3 and 4, Table S5). We found only a weak correlation between aphid abundances in autumn 2016 and spring 2017 (Spearman $r=0.39, p=0.07$ ). For predators, abundance increased slightly with increasing levels of urbanization in spring, but this pattern changed from the beginning of summer, and the abundance was higher in seminatural habitats for the rest of the season. This temporal pattern was more pronounced in 2016 than in 2017. The abundance of ants slightly decreased with the increasing percentage of impervious surfaces on all sampling occasions. Surprisingly, predators and ants did not follow the spatial abundance pattern of aphids in spring and even less in autumn (Figs. 3 and 4, Table S5).

\section{Aphid-predator-ant interactions}

According to the best models, the presence of predators negatively affected the total abundance of aphids in 2016 ( $p=$ 0.013 , Table S6). We found significant negative relationship between monthly predator and total aphid abundance in September and October in 2016. However, there was no association between the yearly or monthly abundances of ants and the total aphid density, either in 2016 or in 2017 (Tables 2 and S7). We did not find any significant relationship between yearly abundances of predators and ants in either year (QuasiGLMs: 2016: $t=0.593, p=0.560 ; 2017: t=-1.176, p=$ $0.253)$.

During the months of peak aphid abundance, number of aphids had no significant effect on the abundance of predators $(p=0.483)$ or ants $(p=0.408)$, i.e. predators and ants did not track aphid abundance (Table S8).

\section{Species of aphids and predators and taxonomic composition of predator community}

The main aphid species showed a positive response to percentage of impervious surfaces. This relationship was significant in the cases of P. testudinaceus in 2016 and $P$. obscurus in 2017 (Table 3, Fig. S3).

The earwig Apterygida media was strongly associated with sites with the lowest percentage of impervious surfaces (where there was a high percentage of forests). In contrast, $F$. auricularia were most abundant at sites with high 
Fig. 1 Monthly abundance of aphid, predator, and ant assemblages in 2016 and 2017. Boxplots show medians, lower, and upper quartiles, whiskers include the range of data without outliers. Note the different scales on the y-axes

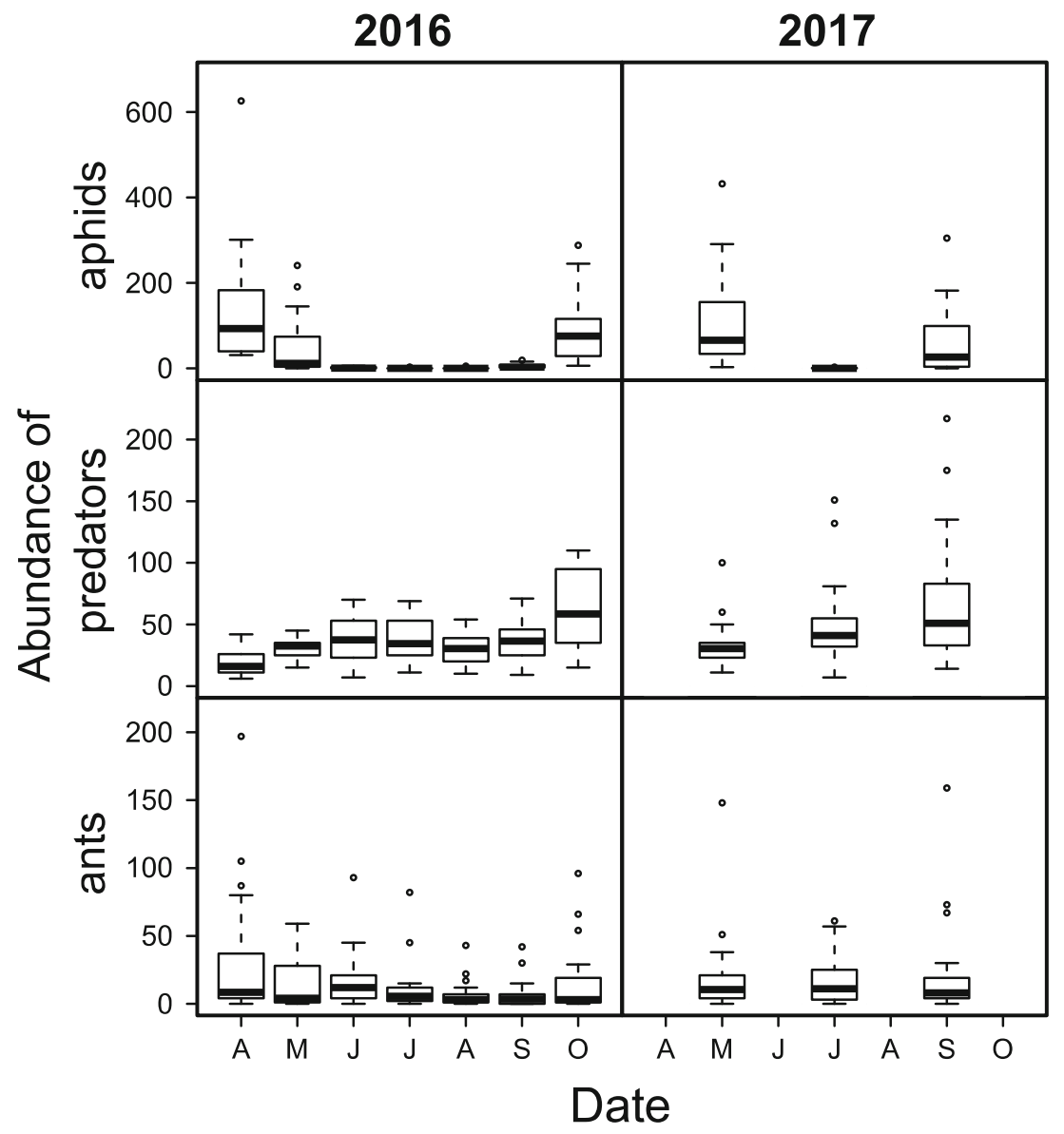

percentages of gardens or urban parks and showed no relationship to the degree of urbanization (Table 3, Fig. S4, for the percentage of each landscape element see Table S2).

Among the true bugs, the abundance of Deraeocoris flavilinea (A. Costa) increased with the increasing level of impervious surfaces. Urbanization had no significant effect

Table 1 Results of quasi-GLMs for the annual abundance of aphids, predators, and ants (total abundance per site, response variables) depending on the percentage of impervious surfaces (explanatory variable)

\begin{tabular}{lrllll}
\hline Response variable & Estimate & SE & Exp. Estimate & $p$ & Pseudo- $R^{2}$ \\
\hline $\mathbf{2 0 1 6}$ & & & & & \\
Sum aphids & 0.011 & 0.004 & 1.011 & $\mathbf{0 . 0 0 8}$ & 30.7 \\
Sum predators & -0.005 & 0.002 & 0.995 & $\mathbf{0 . 0 3 9}$ & 20.3 \\
Sum ants & -0.021 & 0.008 & 0.979 & $\mathbf{0 . 0 1 3}$ & 31.3 \\
$\mathbf{2 0 1 7}$ & & & & & \\
Sum aphids & 0.022 & 0.004 & 1.023 & $\mathbf{0 . 0 0 0}$ & 62.7 \\
Sum predators & -0.003 & 0.004 & 0.997 & 0.472 & 3.0 \\
Sum ants & -0.017 & 0.009 & 0.983 & 0.073 & 19.7 \\
\hline
\end{tabular}

Numbers in bold indicate significant $(p<0.05)$ and numbers in italics indicate marginally significant $(p \geq 0.05$ and $p<0.1) p$ values on the abundance of the rest of the true bug species (Table 3, Fig. S4).

Among aphidophagous coccinellids, the density of $H$. axyridis larvae increased significantly with urbanization, while that of $H$. axyridis adults decreased slightly, in 2016. Urbanization had no effect on the abundance of the rest of the coccinellid species (Table 3, Fig. S5).

Most of the spider species responded negatively to the increase of impervious surfaces. This was particularly true for Anyphaena accentuata (Walckenaer), Araniella spp. [mainly A. cucurbitina (Clerck), and A. opisthographa (Kulczyński)], and for the groups 'other Theridiidae' (mostly juveniles), 'other Thomisidae', but to a lesser extent for Ph. aureolus group. Only Xysticus spp. (mostly juveniles) had significantly higher abundance in built-up areas. Anelosimus vittatus (CL Koch), Cheiracanthium spp. (mainly C. mildei L. Koch) and the Ph. rufus group showed no response to urbanization (Table 3, Fig. S6, for further information on the species groups and genera, see Table S4).

Lacewing abundance (mostly of Chrysoperla carnea [Stephens]) decreased slightly with increasing levels of urbanization in 2016 (Table 3, Fig. S5).

NMDS ordination revealed that the community composition of predators changed along the urbanization gradient in 
Fig. 2 Effect of impervious surface percentage on the abundance of aphid, predator, and ant assemblages in 2016 and 2017. Continuous lines indicate significant $(p<0.05)$, dashed lines indicate marginally significant $(\geq 0.05$ and $<0.1)$, and thin dotted lines indicate nonsignificant ( $p \geq 0.1$ ) effect of impervious surfaces. Note the different scales on the y-axes. Fitted lines are from quasi-Poisson GLMs

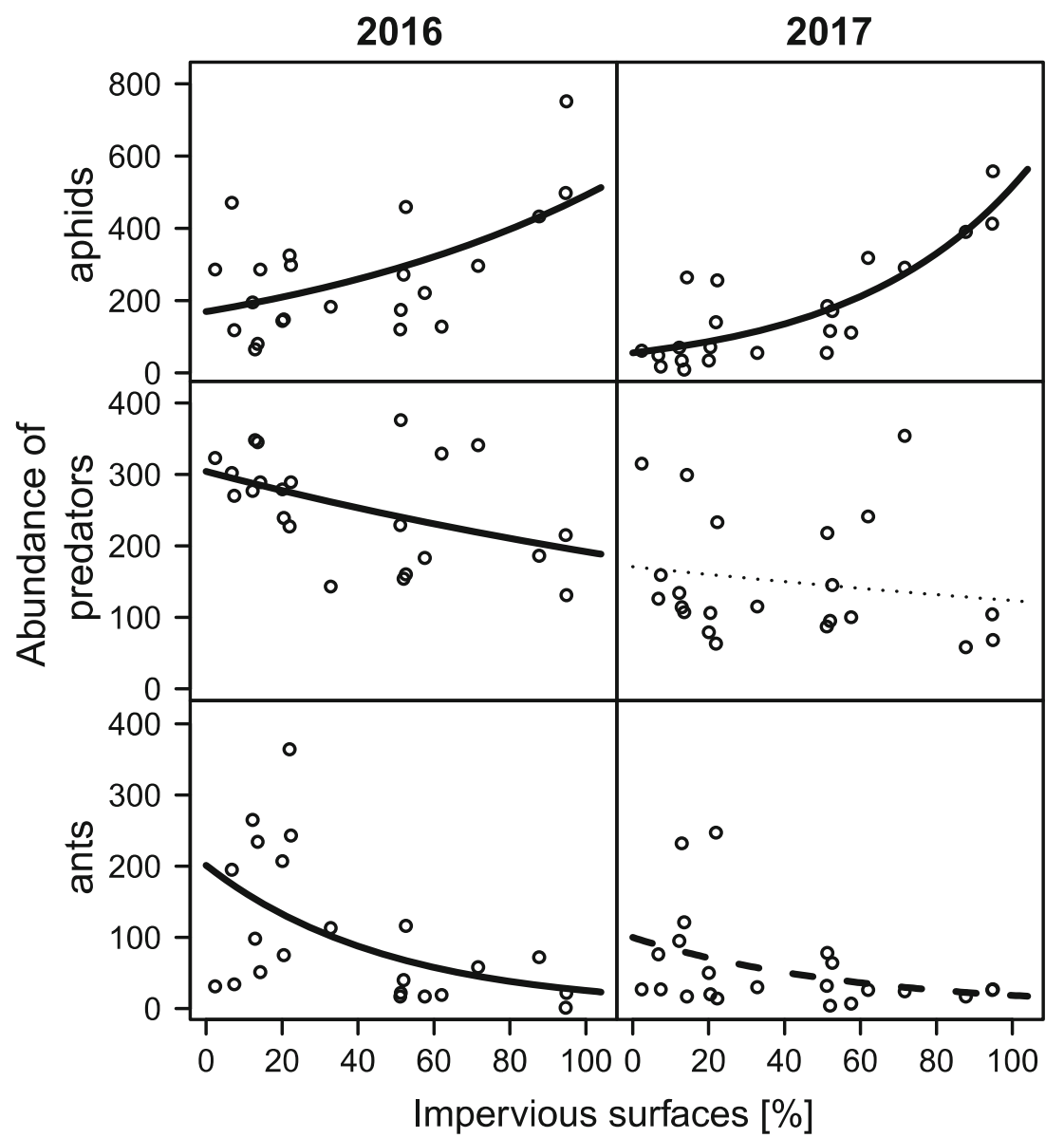

both 2016 and 2017 (NMDS, Stress $=0.186, R^{2}=0.674$; Stress $0.203, R^{2}=0.715$, respectively) (Fig. $5 \mathrm{a}-\mathrm{b}$ ). This pattern was most typical for the spider assemblage (NMDS, Stress $\left.=0.173, R^{2}=0.539\right)$ and to a lesser extent for true bugs and coccinellids (NMDS, Stress $=0.203, R^{2}=0.600$; Stress $=$ $0.198, R^{2}=0.547$, respectively) (Fig. $5 \mathrm{c}-\mathrm{e}$ ). The composition of coccinellids did not separate clearly along the first axis, although it showed differences between the most natural (impervious surface $<20 \%$ ) and highly urbanized sites (impervious surface $>60 \%$ ) (Fig. $5 d$ ).

\section{Effect of dispersal ability of predators on aphids}

We found a significant shift in the CWM trait values for predator dispersal ability along the urbanization gradient in both years, where the proportion of predatory species with higher dispersal ability increased with the increasing level of impervious surfaces (GLMs: 2016: $t=3.156, p=0.005 ; 2017: t=$ $2.448, p=0.024$ ) (Fig. 6), and the annual abundance of aphids decreased significantly when the predator community contained more low-dispersing predators (Quasi-GLMs: 2016: $t=3.05, p=0.006 ; 2017: t=2.385, p=0.027$ ).

According to the NMDS ordination based on the association between the abundance of aphids and predatory groups earwigs (mean dispersal value of the group: $0.0, n=831$ ) and web building spiders $(0.61,649)$ were associated with the sites with the lowest, while $H$. axyridis larvae $(1.0,255)$ and other coccinellids $(1.0,1082)$ were associated with the sites with the highest aphid abundances (NMDS, Stress $=0.113, R^{2}=$ 0.227 ; Stress $=0.155, R^{2}=0.359$, respectively) (Fig. 7).

\section{Discussion}

The aphid-predator-ant system we studied changed markedly both in space, along the urbanization gradient, and in time, across the season, in both study years. Aphids and predatory arthropods showed species-specific abundance patterns. There was a negative relationship between predator and aphid abundances in one of the two study years and the abundance of aphids decreased significantly with increasing number of lowdispersing individuals in the predator community in both years.

\section{Effects of urbanization on the abundance of aphids, predators and ants}

Aphids exhibited the most consistent pattern in this study. In line with our first hypothesis, we found high aphid 
Fig. 3 Effect of impervious surface percentage on the abundance of aphid, predator, and ant assemblages in different months in 2016. Continuous lines indicate significant $(p<0.05)$, dashed lines indicate marginally significant $(\geq 0.05$ and $<0.1)$, and thin dotted lines indicate nonsignificant $(p \geq 0.1)$ effect of impervious surfaces (based on adjusted $p$ values). Between June and September, the aphid numbers were insufficient for statistical analysis. Note the different scales on the y-axes. Fitted lines are from quasi-Poisson GLMs

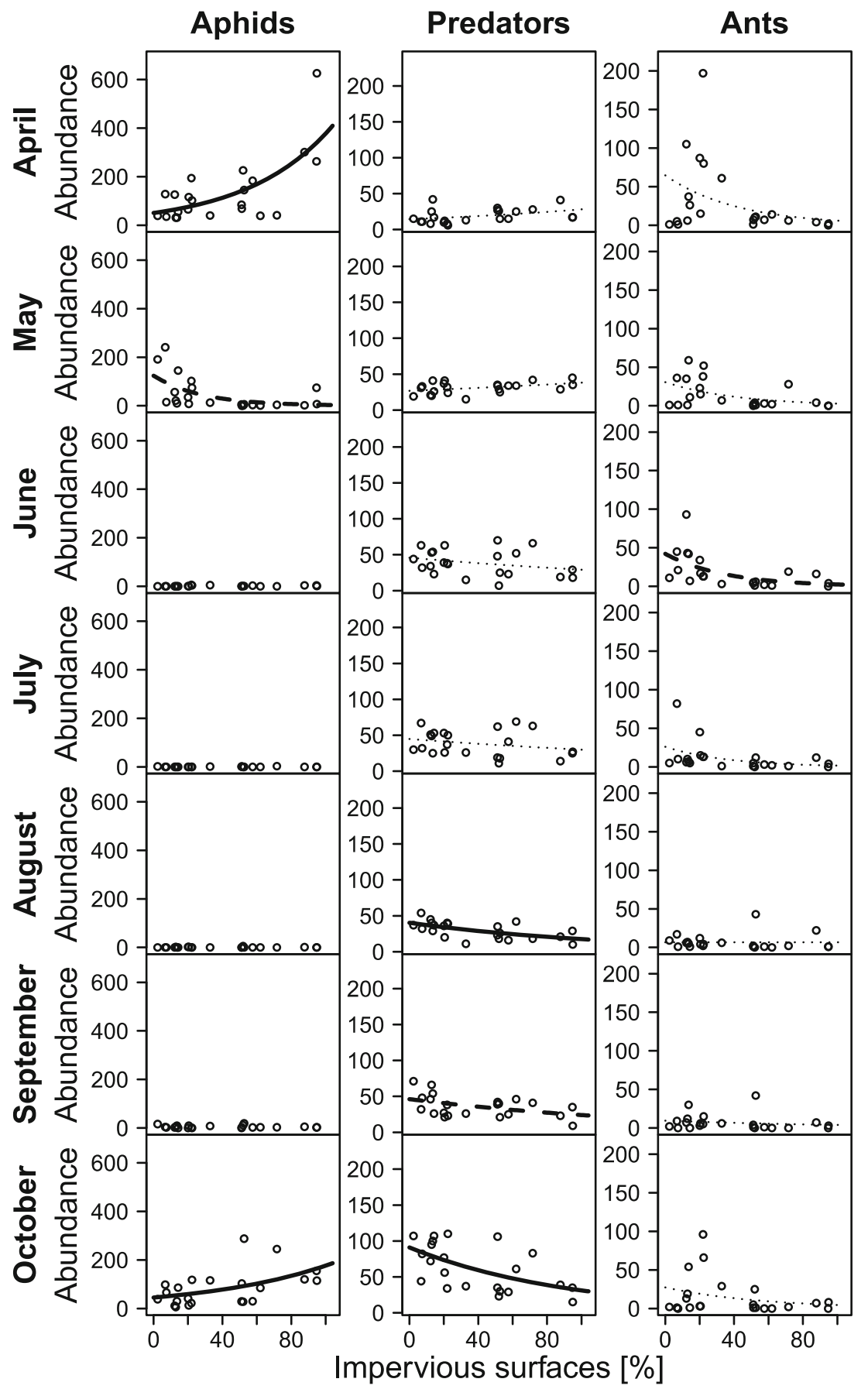

abundances in highly urbanized areas, in contrast to seminatural landscapes where their abundance remained low (Table 1, Fig. 2). Aphids benefit from urbanization disturbance due to the environmental conditions and characteristics of their host plants in cities (Braun and Flückiger 1985; Butler and Trumble 2008; Hall and Ehler 1980) coupled with their enormous reproductive potential and multiple generations per year, which allows them to rapidly take advantage of favorable conditions (Durak et al. 2016; Harrington et al. 2007; Parsons and Frank 2019).
In contrast to aphids, the overall number of predators decreased towards the city center (Table 1, Fig. 2), which can be explained by several factors. Highly urbanized areas are generally characterized by fragmented habitats with reduced plant density, diversity, and structural complexity (Raupp et al. 2010). This may create an unfavorable environment for predators due to reduced numbers of prey (and alternative resources), refuges, and suboptimal climatic conditions (Langellotto and Denno 2004). Moreover, the increasing proportion of human-made structures might act as a dispersal 
Fig. 4 Effect of impervious surface percentage on the abundance of aphid, predator, and ant assemblages in different months in 2017. Continuous lines indicate significant $(p<0.05)$, thin dotted lines indicate nonsignificant $(p \geq 0.1)$ effect of impervious surfaces (based on adjusted $p$ values). Aphid numbers were insufficient for statistical analysis in July. Note the different scales on the y-axes. Fitted lines are from quasi-Poisson GLMs

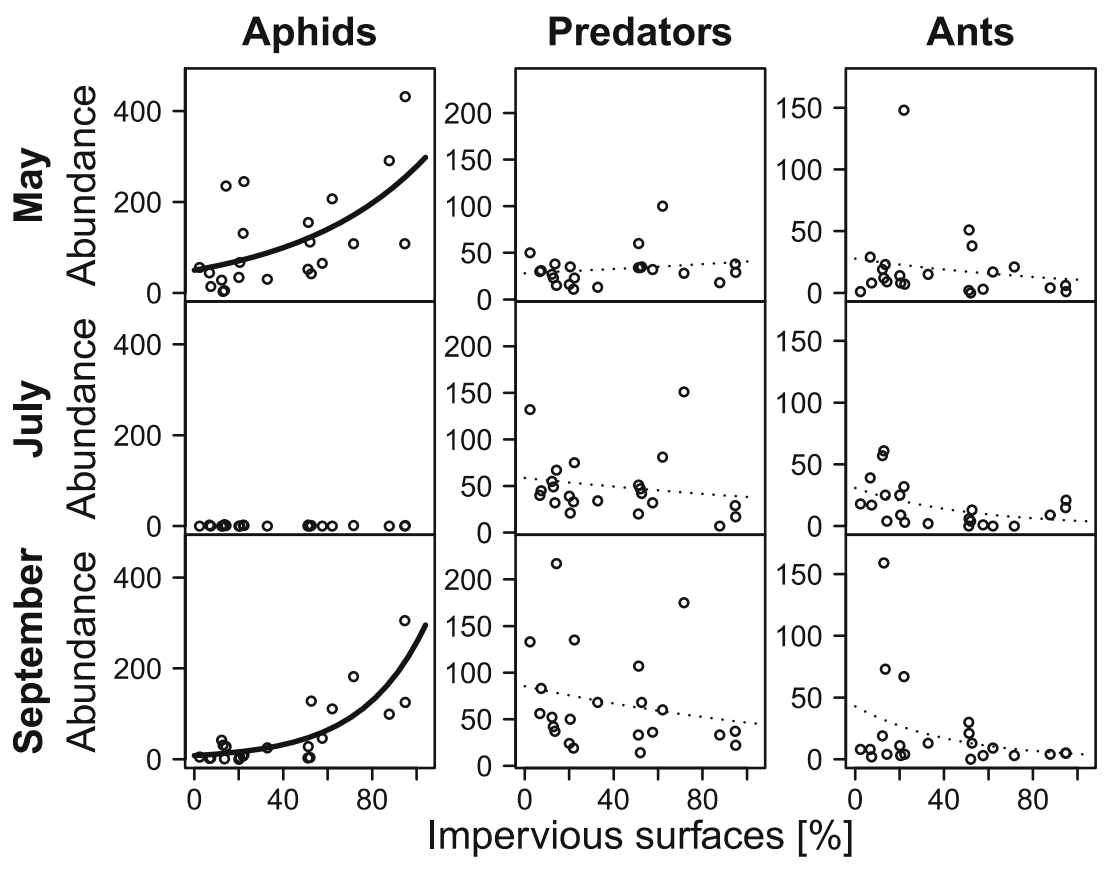

barrier for predatory arthropods (Denys and Schmidt 1998; Mader et al. 1990; Turrini et al. 2016).

Lessard and Buddle (2005) found the highest ant abundance in residential backyards compared to forests while Rocha and Fellowes (2018) showed that ants were present in high numbers even at the most urbanized sites. Contrary to their findings, we observed that ants had the highest abundance in semi-natural areas and the lowest in the city center (Table 1, Fig. 2). Although we did not determine the species composition of ants along the gradient, we assume that highly urbanized areas are less suitable habitats for most of the ant species. The explanation for this could be colonization limitation, as individual ants may have more limited opportunities to spread to more isolated areas from source populations (Pacheco and Vasconcelos 2007), but also may be due to a lack of necessary resources for nesting sites (Vepsäläinen et al. 2008) and a decline in soil moisture (Clarke et al. 2008).

Generally, the activity of tree-dwelling aphids is characterized by two seasonal peaks (Dixon 1977; Piñol et al. 2009a, 2009b), and we found the same pattern here (Fig. 1). Periphyllus species aestivate during summer months as first instar nymphs, while Drepanosiphum species aestivate as adults (Dixon 1977; Dixon 1998; Furuta 1985; Junkiert et al. 2011). Although the total abundance of aphids increased towards the city center in both years, their monthly abundance showed a less consistent pattern. The abundance of aphids greatly increased in April, but slightly decreased in May towards the city center in 2016 (Fig. 3, Table S5). Highly urbanized areas generally have higher temperatures than the surrounding semi-natural habitats due to the urban heat island effect caused by the high proportion of impervious surfaces (Long et al. 2019; Rizwan et al. 2008). Since temperature is considered one of the most important factors in aphid development (Durak et al. 2016; Harrington et al. 2007), it is possible that warmer temperatures resulted in faster nymphal development (phenological shift) at these sites compared to semi-natural habitats (Fig. 3, Table S5). Higher temperature can also lead to delayed appearance of sexual generations and reproduction of aphids at the end of summer (Durak et al. 2016). Based on these factors, we expected an earlier peak in aphid abundance in semi-natural habitats compared to highly urbanized ones in this period, but such a pattern was not observed (Fig. 3). The lack of a phenological shift in the later part of the season may be explained by greater predator
Table 2 Results of the best quasiGLMs (after model selection) for the annual abundance of aphids (response variable) depending on the monthly abundance of predators and ants (explanatory variables)

\begin{tabular}{llllllll}
\hline Explanatory variable & Month & Estimate & SE & Exp. Estimate & Adj. $p$ & Unadj. $p$ & Pseudo- $R^{2}$ \\
\hline Predators & June & -0.013 & 0.007 & 0.987 & 0.148 & 0.089 & 14.9 \\
Predators & September & -0.024 & 0.008 & 0.976 & $\mathbf{0 . 0 3 0}$ & $\mathbf{0 . 0 0 6}$ & 34.4 \\
Predators & October & -0.010 & 0.004 & 0.990 & $\mathbf{0 . 0 3 5}$ & $\mathbf{0 . 0 1 4}$ & 27.5 \\
\hline
\end{tabular}

Only significant ( $p<0.05$, numbers in bold) and marginally significant ( $p \geq 0.05$ and $<0.1$, number in italics) results are shown for the best models (in 2016). The main outcomes of the best and full models are summarized in Table S7 
Table 3 Relationships between impervious surface percentage and the abundance of aphid and predator taxa

\begin{tabular}{|c|c|c|c|c|c|c|c|c|c|c|}
\hline \multirow[t]{2}{*}{ Taxon } & \multicolumn{5}{|l|}{2016} & \multicolumn{5}{|l|}{2017} \\
\hline & Estimate & SE & $\begin{array}{l}\text { Exp. } \\
\text { Estimate }\end{array}$ & Adj. $p$ & Pseudo- $\mathrm{R}^{2}$ & Estimate & SE & $\begin{array}{l}\text { Exp. } \\
\text { Estimate }\end{array}$ & Adj. $p$ & Pseudo- $\mathrm{R}^{2}$ \\
\hline \multicolumn{11}{|l|}{ Sternorrhyncha } \\
\hline Drepanosiphum aceris & 0.008 & 0.012 & 1.008 & $0.514(0.514)$ & 3.1 & - & - & - & - & - \\
\hline Drepanosiphum platanoidis & 0.018 & 0.008 & 1.018 & $0.096(\mathbf{0 . 0 4 8})$ & 23.9 & - & - & - & - & - \\
\hline Periphyllus obscurus & 0.008 & 0.005 & 1.008 & $0.192(0.144)$ & 11.0 & 0.032 & 0.005 & 1.033 & $0.000(0.000)$ & 74.5 \\
\hline Periphyllus testudinaceus & 0.011 & 0.004 & 1.011 & $0.049(0.012)$ & 28.0 & 0.011 & 0.006 & 1.011 & $0.111(0.111)$ & 13.2 \\
\hline \multicolumn{11}{|l|}{ Dermaptera } \\
\hline Apterygida media & -0.112 & 0.049 & 0.894 & $0.068(\mathbf{0 . 0 3 4})$ & 53.3 & -0.133 & 0.046 & 0.876 & $0.019(0.010)$ & 55.6 \\
\hline Forficula auricularia & -0.008 & 0.007 & 0.992 & $0.270(0.270)$ & 6.3 & -0.002 & 0.009 & 0.998 & $0.820(0.820)$ & 0.3 \\
\hline \multicolumn{11}{|l|}{ Heteroptera } \\
\hline Deraeocoris flavilinea & 0.021 & 0.007 & 1.021 & $0.035(0.005)$ & 34.8 & - & - & - & - & - \\
\hline Deraeocoris lutescens & -0.005 & 0.005 & 0.995 & $0.490(0.350)$ & 4.9 & -0.003 & 0.009 & 0.997 & $0.761(0.761)$ & 0.6 \\
\hline Orius spp. & 0.000 & 0.007 & 1.000 & $0.992(0.992)$ & 0.0 & -0.003 & 0.007 & 0.997 & $0.761(0.733)$ & 0.5 \\
\hline Phytocoris tiliae & 0.018 & 0.008 & 1.018 & $0.103(\mathbf{0 . 0 4 4 )}$ & 18.7 & - & - & - & - & - \\
\hline Pilophorus perplexus & -0.036 & 0.016 & 0.964 & $0.103(\mathbf{0 . 0 3 4})$ & 33.7 & - & - & - & - & - \\
\hline Psallus assimilis & 0.006 & 0.005 & 1.006 & $0.424(0.242)$ & 6.3 & 0.029 & 0.015 & 1.030 & $0.199(0.060)$ & 27.5 \\
\hline Reuteria marqueti & -0.007 & 0.014 & 0.993 & $0.708(0.606)$ & 1.8 & - & - & - & - & - \\
\hline \multicolumn{11}{|l|}{ Coleoptera } \\
\hline Coccinella septempunctata & -0.005 & 0.014 & 0.995 & $0.755(0.717)$ & 1.2 & - & - & - & - & - \\
\hline Exochomus quadripustulatus & -0.002 & 0.007 & 0.998 & $0.755(0.755)$ & 0.5 & 0.004 & 0.006 & 1.004 & $0.490(0.490)$ & 2.2 \\
\hline Harmonia axyridis larvae & 0.015 & 0.004 & 1.015 & $0.019(0.003)$ & 35.1 & - & - & - & - & - \\
\hline Harmonia axyridis adults & -0.011 & 0.005 & 0.989 & $0.121(\mathbf{0 . 0 4 7})$ & 21.5 & -0.004 & 0.004 & 0.996 & $0.490(0.380)$ & 4.2 \\
\hline Oenopia conglobata & 0.014 & 0.007 & 1.014 & $0.121(0.072)$ & 15.7 & 0.018 & 0.012 & 1.018 & $0.466(0.155)$ & 12.2 \\
\hline Scymnus spp. & 0.013 & 0.007 & 1.013 & $0.121(0.080)$ & 13.0 & - & - & - & - & - \\
\hline \multicolumn{11}{|l|}{ Neuroptera } \\
\hline Chrysoperla spp. & -0.016 & 0.008 & 0.984 & $0.078(0.078)$ & 15.3 & - & - & - & - & - \\
\hline \multicolumn{11}{|l|}{ Araneae } \\
\hline Anelosimus vittatus & - & - & - & - & - & 0.002 & 0.014 & 1.002 & $0.880(0.880)$ & 0.2 \\
\hline 'other Theridiidae' & -0.017 & 0.005 & 0.983 & $0.012(0.001)$ & 41.7 & -0.020 & 0.009 & 0.981 & $0.072(\mathbf{0 . 0 4 0})$ & 26.8 \\
\hline Anyphaena accentuata & -0.087 & 0.039 & 0.917 & $0.091(\mathbf{0 . 0 4 0})$ & 70.2 & -0.091 & 0.030 & 0.913 & $0.023(0.008)$ & 62.3 \\
\hline Araniella spp. & -0.022 & 0.010 & 0.978 & $0.091(\mathbf{0 . 0 3 8})$ & 26.2 & -0.032 & 0.010 & 0.968 & $0.018(0.004)$ & 48.0 \\
\hline Cheiracanthium spp. & 0.005 & 0.006 & 1.005 & $0.470(0.418)$ & 3.1 & -0.003 & 0.005 & 0.997 & $0.624(0.485)$ & 1.9 \\
\hline Philodromus spp. aureolus gr. & -0.007 & 0.003 & 0.993 & $0.091(\mathbf{0 . 0 3 5})$ & 20.2 & -0.009 & 0.004 & 0.991 & $0.078(0.052)$ & 18.1 \\
\hline Philodromus spp. rufus gr. & 0.004 & 0.008 & 1.004 & $0.585(0.585)$ & 1.9 & 0.003 & 0.008 & 1.003 & $0.820(0.729)$ & 0.7 \\
\hline Xysticus spp. & - & - & - & - & - & 0.013 & 0.005 & 1.014 & $0.032(0.014)$ & 22.6 \\
\hline 'other Thomisidae' & -0.088 & 0.058 & 0.916 & $0.213(0.142)$ & 56.0 & -0.052 & 0.016 & 0.949 & $0.018(0.004)$ & 56.4 \\
\hline
\end{tabular}

Summary of the quasi-GLM results by species and years. Numbers with bold indicate significant $(<0.05)$ and numbers with italic indicate marginally significant $(\geq 0.05$ and $<0.1) p$ values. Numbers in parentheses are the unadjusted $p$ values

abundances and therefore higher predation rates in seminatural areas that might obscure the impact of climate on aphids.

The overall number of predators was relatively low and only increased slightly towards the city center in spring (mostly due to $H$. axyridis larvae and some true bugs). Predator abundance started to increase towards the semi-natural areas from the beginning of June (mostly due to earwigs and coccinellids, including $H$. axyridis adults), and this pattern was most pronounced in autumn (mostly due to spiders and coccinellids) (Figs. 3 and 4, Table S5, Fig. S2).

Predatory insects with high dispersal ability and ants exhibit positive density-dependent numerical responses to aphid density (Brown 2004; Leigh and van Emden 2017; Markó et al. 2013; Stutz and Entling 2011). However, in our study, predatory arthropods and ants showed a reverse pattern 
Fig. 5 NMDS ordination of the 22 sites based on community composition of all predators in (a) 2016 and (b) 2017; in case of (c) true bugs, (d) aphidophagous ladybirds and (e) spiders. For the three predator groups, the data of May, July, and September in 2016 and 2017 were pooled. Grey circles represent study sites. GAM fitted isoclines represent impervious surface percentages a)

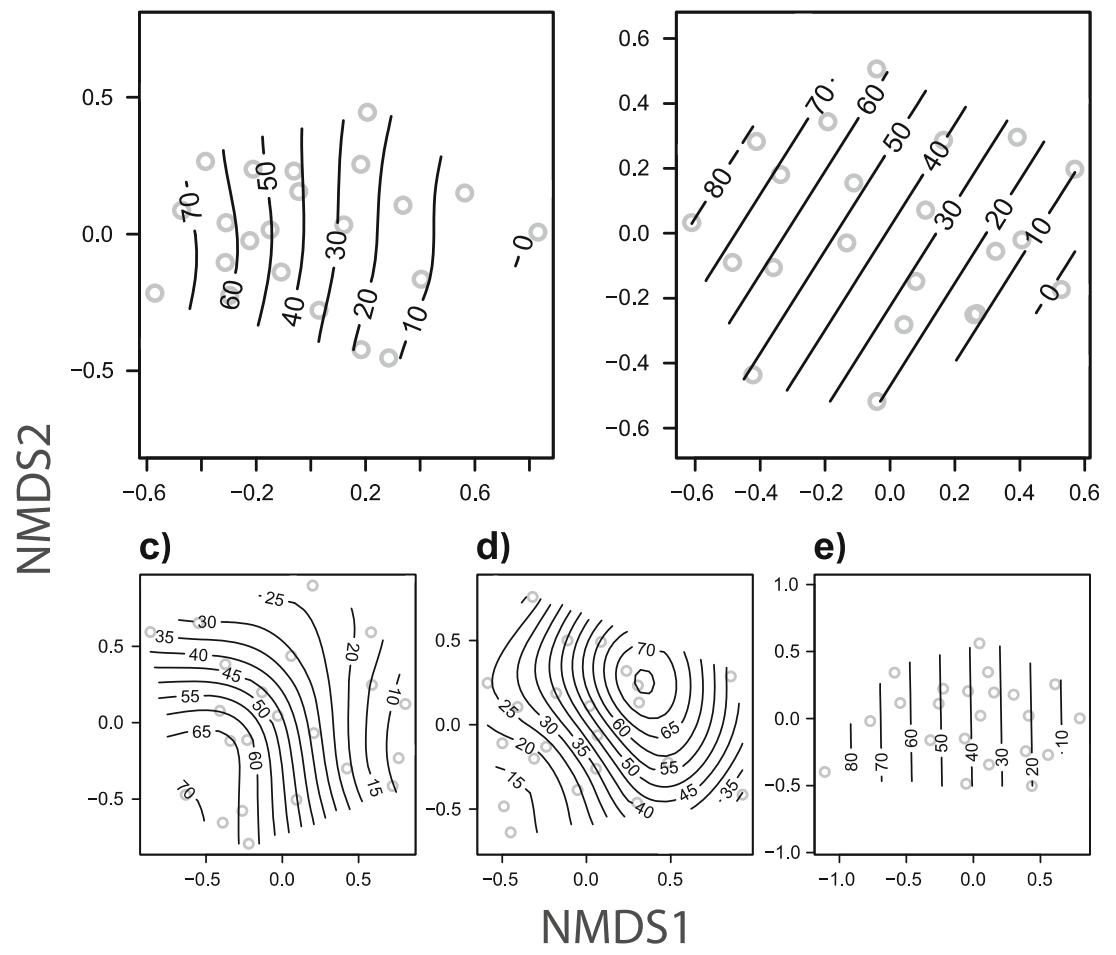

compared to aphids, i.e. the abundance of predators and ants did not track the abundance of aphids along the urbanization gradient even at the aphid peaks in spring and autumn (Figs. 3 and 4, Tables S5 and S8). This finding indicates that urbanization may lead to a spatial mismatch between aphids, their predators, and mutualistic ants.

\section{Aphid-predator-ant interactions}

In line with our second hypothesis, high predator numbers were accompanied by low aphid abundance in 2016, but contrary to our expectations (and hypothesis 3 ), there was no relationship between ant and aphid abundance (Tables 2 and S7), and predatory arthropods and ants varied independently of each other. One explanation for the observed higher aphid densities in more urbanized areas may be that urbanization disrupted predators, resulting in weakened top-down control on aphids (Turrini et al. 2016). Predators reached their highest abundance in autumn (Fig. 1; Table S8), and predator abundances were the best predictors of the total aphid abundance in this period in 2016 (Tables 2 and S7). This suggests that number of aphids is primarily regulated by predators before and during their second activity peak in semi-natural areas. Furuta (1985) pointed out that aestivating populations of Periphyllus californiensis (Shinji) on maple trees seem to face high predation in the second half of the growing season, and this may have a stronger effect on their survival than other factors such as unfavorable climatic conditions.

The highest aphid densities were coincided with the lowest predator densities at the beginning of the growing season. This
Fig. 6 Effect of impervious surface percentage on community weighted mean (CWM) dispersal values of predators in (a) 2016 and (b) 2017
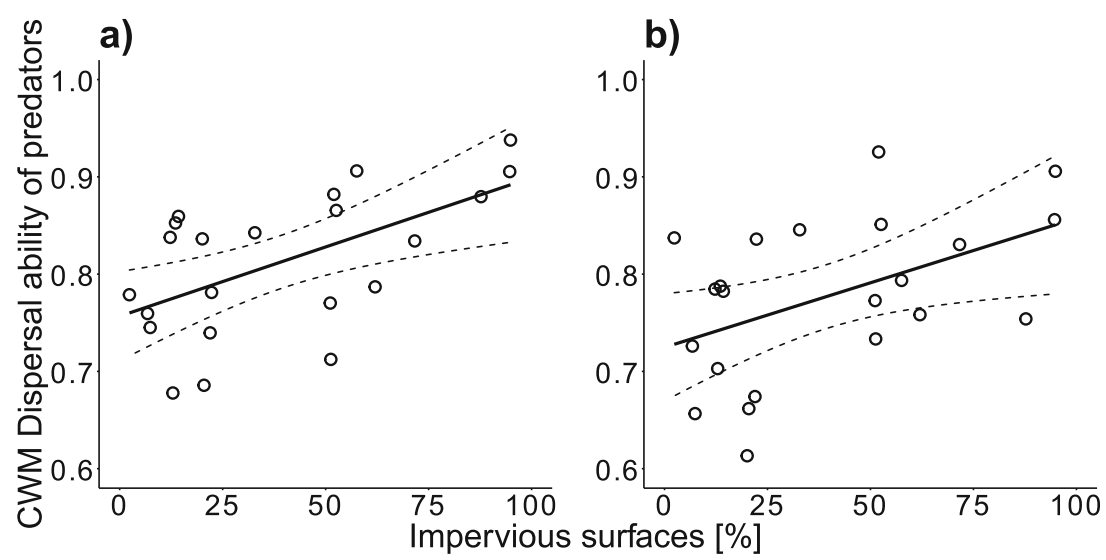


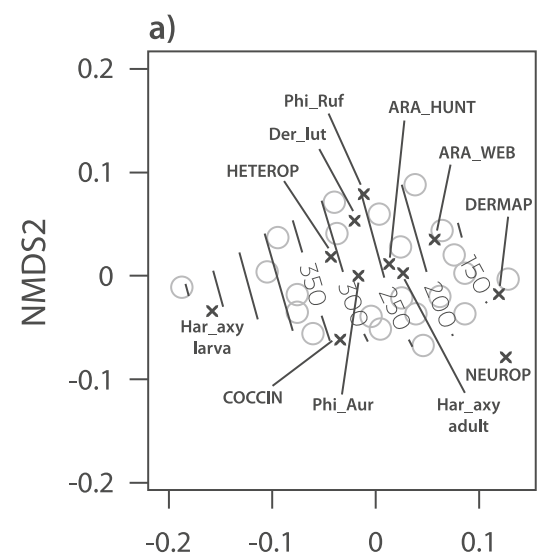

Fig. 7 NMDS ordination of total abundances of predators in (a) 2016 and (b) 2017. Grey circles represent study sites and abbreviations correspond to the most abundant natural enemy groups (DERMAP: Dermaptera, HETEROP: other heteropterans (except D. lutescens), Der_lut: Deraeocoris lutescens, COCCIN: other coccinellids (except Harmonia axyridis larvae and adults), Har_axy larva: Harmonia axyridis larvae,

implies that aphid species with early egg hatch (especially $P$. testudinaceus) are exposed to lower predation in spring (Dixon 1998), and therefore the peak in aphid density early in the season might be determined more by aphid abundance in the previous autumn than by predation in early spring. Rocha and Fellowes (2018) reported that instead of predation, the abundance of mutualistic ants drove the abundance of myrmecophilous aphids along the urbanization gradient. Contrary to their results and to those of Skinner and Whittaker (1981), we found that the supposed positive effect of ants on aphids did not override the predation pressure on aphids (almost exclusively ant-tended Periphyllus spp.) in semi-natural areas.

\section{Species of aphids and predators and taxonomic composition of predator community}

The ant-tended aphid species (P. obscurus, $P$. testudinaceus) responded positively, while the non-ant-tended species (D. aceris, D. platanoidis) showed no or weak responses to increasing level of urbanization. In contrast, and in line with hypothesis 4 , predatory species showed definitive speciesspecific responses (Table 3). Seven predatory groups responded negatively, whereas three groups responded positively to urbanization in at least one of the studied years. Fourteen groups showed no response to urbanization and were occasionally abundant in moderately built-up sites but less often in highly built-up areas.

One earwig species and most of the spider groups were negatively affected by urbanization. In contrast, most true bugs and coccinellids showed no response or responded positively to increasing levels of urbanization (Table 3, Figs. S4, S5 and S6). b)

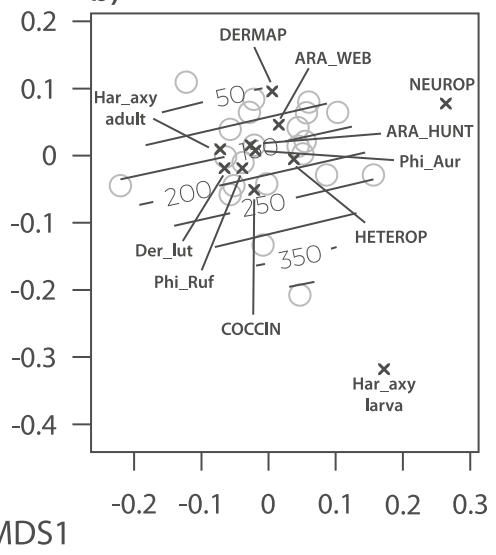

Har_axy adult: Harmonia axyridis adults, NEUROP: Neuroptera, ARA WEB: web building spiders, ARA HUNT: other hunting spiders (except Philodromus aureolus and rufus groups), Phi_Aur: Philodromus aureolus group, Phi_Ruf: Philodromus rufus group). GAM fitted isoclines represent aphid abundances

In accordance with species-specific responses, the composition of spiders changed more along the urbanization gradient than that of true bugs or coccinellids (Fig. 5c-e), and based on this, spiders contributed most significantly to the changing composition pattern of the total predator community in both years (Fig. 5a-b). These results suggest that although some spider groups have a wide habitat range and good dispersal ability (Alaruikka et al. 2002; Blandenier 2009; Duffey 1956), they are less capable of target-oriented movement than the winged species with relatively high mobility and short residency time such as coccinellids and true bugs (Egerer et al. 2016; Piñol et al. 2009b). Therefore, spiders can be highly sensitive to habitat isolation and its consequences caused by urbanization (Argañaraz et al. 2018; Langellotto and Denno 2004; Meineke et al. 2017).

It is important to mention that in some cases we also recorded high predator densities (e.g. F. auricularia, D. lutescens, P. assimilis, E. quadripustulatus, O. conglobata, and Scymnus spp.) in moderately built-up sites with relatively high share of parks and gardens (Table S2, Figs. S4 and S5). These kind of green areas in cities are complex, resource-rich habitats, and are preferred by certain predatory species such as coccinellids (Egerer et al. 2016; Honěk et al. 2017) and other aphidophagous predators (Parsons and Frank 2019). However, a high proportion of impervious surfaces in the surrounding environment may influence the colonization success even of these species (Comont et al. 2014; Rocha et al. 2018).

\section{Effect of dispersal ability of predators on aphids}

We found that the dispersal capacity of predator community significantly increased with increasing level of 
urbanization, suggesting that urbanization filters predatory species based on their dispersal ability (Merckx and Van Dyck 2019; Piano et al. 2017). Furthermore, our observations are consistent with hypothesis 5 and suggest that generalist predators with low dispersal ability such as earwigs and some spiders may play a major role in the biological control of aphids. Some of these predators can be present constantly on the trees, even at early aphid population growth and low aphid density (Piñol et al. 2009b), which can be an important prerequisite for successful aphid suppression (Boreau de Roincé et al. 2013; Gómez-Marco et al. 2016; Nagy et al. 2015).

Earwigs are voracious predators of aphids and play a key role in the top-down control of these pests (Carroll and Hoyt 1984; Mueller et al. 1988; Piñol et al. 2009a). They are characterized by low dispersal ability and a preference for habitats with higher humidity (Kirstová et al. 2019). Therefore, increasing isolation of trees from forests is associated with lower earwig numbers and, as a consequence, greater density of aphids (Stutz and Entling 2011). There are a few examples where hunting spiders (e.g. Anyphaena, Philodromus spp.) contributed to the early biological control of aphids (Boreau de Roincé et al. 2013; Lefebvre et al. 2017). Moreover, studies showed that web-building spiders can substantially reduce the number of aphids, especially in autumn when density of their webs is high and winged aphids are present. This can lead to fewer aphid fundatrices the following spring (Cahenzli et al. 2017; Wyss et al. 1995).

Our results are in accordance with the finding that predators with high dispersal capacity such as lady beetles and true bugs can be generally less effective at keeping aphid populations at low levels, as they mostly track aphid density rather than control it (Piñol et al. 2009a, 2009b).

\section{Conclusions}

The most important finding of our study is that an increasing level of urbanization resulted in increasing aphid infestations on urban maple trees, while predators showed opposite abundance pattern. Overall dispersal ability of predator community was positively related to urbanization, i.e. predatory species with low dispersal but high aphid control ability (such as earwigs and some spiders) decreased in abundance toward city centers. In contrast, species with higher dispersal potential but a lower ability to prevent aphid outbreaks such as coccinellids and true bugs did not aggregate in sufficient number on the abundant aphid colonies to compensate for the lack of early aphid control in the city centers by other predators. We concluded that aphid populations in semi-natural habitats are primarily regulated at low aphid densities by predators with low dispersal ability. In this study, ants were less abundant in urban than in the semi-natural habitats and did not drive aphid density.

Our results suggest that pest control services provided by predatory arthropods decrease markedly towards city centers and are associated with aphid outbreaks on urban trees. To confirm this, further field studies combined with experimental approaches are needed.

Acknowledgements We would like to thank László Gallé, Ottó Merkl and Ferenc Szentkirályi for their help in the identification of ants, Scymnus species and lacewings, respectively, furthermore Patrícia Orbán and Rebeka Saliga for their help in field sampling and processing of the collected samples. We also thank two anonymous reviewers for their helpful comments and suggestions. This research was supported by the National Research, Development and Innovation Office of Hungary (K129311) and by the Ministry for Innovation and Technology within the framework of the Higher Education Institutional Excellence Program (NKFIH-1159-6/2019) in the scope of plant breeding and plant protection research of Szent István University.

Funding Open access funding provided by ELKH Centre for Ecological Research.

Open Access This article is licensed under a Creative Commons Attribution 4.0 International License, which permits use, sharing, adaptation, distribution and reproduction in any medium or format, as long as you give appropriate credit to the original author(s) and the source, provide a link to the Creative Commons licence, and indicate if changes were made. The images or other third party material in this article are included in the article's Creative Commons licence, unless indicated otherwise in a credit line to the material. If material is not included in the article's Creative Commons licence and your intended use is not permitted by statutory regulation or exceeds the permitted use, you will need to obtain permission directly from the copyright holder. To view a copy of this licence, visit http://creativecommons.org/licenses/by/4.0/.

\section{References}

Alaruikka D, Kotze DJ, Matveinen K, Niemelä J (2002) Carabid beetle and spider assemblages along a forested urban-rural gradient in southern Finland. J Insect Conserv 6:195-206. https://doi.org/10. 1023/A:1024432830064

Alberti M (1999) Urban patterns and environmental performance: what do we know? J Plan Educ Res 19:151-163. https://doi.org/10.1177/ 0739456X9901900205

Argañaraz CI, Rubio GD, Gleiser RM (2018) Spider communities in urban green patches and their relation to local and landscape traits. Biodivers Conserv 27:981-1009. https://doi.org/10.1007/s10531017-1476-8

Bartha D, Király G, Schmidt D, Tiborcz V, Bán, M (2018) Hungarian Flora Atlas. Hungarian Flora Mapping database, Sopron, Hungary. http://floraatlasz.uni-sopron.hu/index.php?lang=en. Accessed 19 Jul 2019

Basset Y, Aberlenc H-P, Springate ND, Delvare G (1997) A review of methods for sampling arthropods in tree canopies. In: Stork NE, 
Adis JA, Didham RK (eds) Canopy arthropods. Chapman \& Hall, London, pp 27-52

Bell JR, Bohan DA, Shaw EM, Weyman GS (2005) Ballooning dispersal using silk: world fauna, phylogenies, genetics and models. Bull Entomol Res 95:69-114. https://doi.org/10.1079/BER2004350

Benjamini Y, Hochberg Y (1995) Controlling the false discovery rate: a practical and powerful approach to multiple testing. J R Stat Soc Ser B 57:289-300. https://doi.org/10.1111/j.2517-6161.1995.tb02031.x

Bivand RS, Wong DWS (2018) Comparing implementations of global and local indicators of spatial association. Test 27:716-748. https:// doi.org/10.1007/s11749-018-0599-x

Blackman RL, Eastop VF (2000) Aphids on the world's crops: an identification and information guide, 2nd edn. John Wiley \& Sons, Chichester

Blandenier G (2009) Ballooning of spiders (Araneae) in Switzerland: general results from an eleven-year survey. Bull Br Arachnol Soc 14:308-317. https://doi.org/10.13156/arac.2009.14.7.308

Boreau de Roincé C, Lavigne C, Mandrin J, Rollard C, Symondson W (2013) Early-season predation on aphids by winter-active spiders in apple orchards revealed by diagnostic PCR. B Entomol Rese 103: 148-154. https://doi.org/10.1017/S0007485312000636

Braun S, Flückiger W (1985) Increased population of the aphid Aphis pomi at a motorway: part 3-the effect of exhaust gases. Environ Pollut (Series A) 39:183-192. https://doi.org/10.1016/01431471(85)90016-9

Brown MW (2004) Role of aphid predator guild in controlling spirea aphid populations on apple in West Virginia, USA. Biol Control 29:189-198. https://doi.org/10.1016/S1049-9644(03)00153-1

Burkman CE, Gardiner MM (2014) Urban greenspace composition and landscape context influence natural enemy community composition and function. Biol Control 75:58-67. https://doi.org/10.1016/j. biocontrol.2014.02.015

Butler CD, Trumble JT (2008) Effects of pollutants on bottom-up and top-down processes in insect-plant interactions. Environ Pollut 156: 1-10. https://doi.org/10.1016/j.envpol.2007.12.026

Cahenzli F, Pfiffner L, Daniel C (2017) Reduced crop damage by selfregulation of aphids in an ecologically enriched, insecticide-free apple orchard. Agron Sustain Dev 37:1-8. https://doi.org/10.1007/ s13593-017-0476-0

Carroll DP, Hoyt SC (1984) Augmentation of European earwigs (Dermaptera: Forficulidae) for biological control of apple aphid (Homoptera: Aphididae) in an apple orchard. J Econ Entomol 77: 738-740. https://doi.org/10.1093/jee/77.3.738

Clarke KM, Fisher BL, LeBuhn G (2008) The influence of urban park characteristics on ant (Hymenoptera, Formicidae) communities. Urban Ecosyst 11:317-334. https://doi.org/10.1007/s11252-0080065-8

Comont RF, Roy HE, Harrington R, Shortall CR, Purse BV (2014) Ecological correlates of local extinction and colonisation in the British ladybird beetles (Coleoptera: Coccinellidae). Biol Invasions 16:1805-1817. https://doi.org/10.1007/s10530-013-0628-3

Corcos D, Cerretti P, Caruso V, Mei M, Falco M, Marini L (2019) Impact of urbanization on predator and parasitoid insects at multiple spatial scales. PLoS One 14:e0214068. https://doi.org/10.1371/journal. pone. 0214068

Crumb SE, Eide PM, Bonn AE (1941) The European earwig. USDA Tech Bull 766:1-76

Denys C, Schmidt H (1998) Insect communities on experimental mugwort (Artemisia vulgaris L.) plots along an urban gradient. Oecologia 113:269-277. https://doi.org/10.1007/s004420050378

Dixon AFG (1977) Aphid ecology: life cycles, polymorphism, and population regulation. Annu Rev Ecol Syst 8:329-353. https://doi.org/ 10.1146/annurev.es.08.110177.001553

Dixon AFG (1998) Aphid ecology: an optimization approach, 2nd edn. Chapman and Hall, New York
Duffey E (1956) Aerial dispersal in a known spider population. J Anim Ecol 25:85-111. https://doi.org/10.2307/1852

Durak R, Wegrzyn E, Leniowski K (2016) Do all aphids benefit from climate warming? An effect of temperature increase on a native species of temperate climatic zone Cinara juniperi. Ethol Ecol Evol 28:188-201. https://doi.org/10.1080/03949370.2015.1034785

Egerer MH, Bichier P, Philpott SM (2016) Landscape and local habitat correlates of lady beetle abundance and species richness in urban agriculture. Ann Entom Soc Am 110:97-103. https://doi.org/10. 1093/aesa/saw063

Eötvös CB, Magura T, Lövei GL (2018) A meta-analysis indicates reduced predation pressure with increasing urbanization. Landscape Urban Plan 180:54-59. https://doi.org/10.1016/j.landurbplan.2018. 08.010

Furuta K (1985) Spatial distribution and mortality of aestivating dimorphs of the maple aphid, Periphyllus californiensis Shinji (Homoptera, Aphididae). Z Angew Entomol 100:256-264. https://doi.org/10. 1111/j.1439-0418.1985.tb02778.x

Gómez-Marco F, Tena A, Jaques JA, García AU (2016) Early arrival of predators controls Aphis spiraecola colonies in citrus clementines. J Pest Sci 89:69-79. https://doi.org/10.1007/s10340-015-0668-9

Gossner MM, Simons NK, Achtziger R, Blick T, Dorow WHO, Dziock F, Köhler F, Rabitsch W, Weisser WW (2015) A summary of eight traits of Coleoptera, Hemiptera, Orthoptera and Araneae, occurring in grasslands in Germany. Sci Data 2:150013. https://doi.org/10. 1038/sdata.2015.13

Hall RW, Ehler LE (1980) Population ecology of Aphis nerii on oleander. Environmental Entomol 9:338-344. https://doi.org/10.1093/ee/9.3. 338

Harrington R, Clark SJ, Welham SJ et al (2007) Environmental change and the phenology of European aphids. Glob Chang Biol 13:1550 1564. https://doi.org/10.1111/j.1365-2486.2007.01394.x

Honěk A, Dixon AF, Soares AO, Skuhrovec J, Martinkova Z (2017) Spatial and temporal changes in the abundance and composition of ladybird (Coleoptera: Coccinellidae) communities. Curr Opin Insect Sci 20:61-67. https://doi.org/10.1016/j.cois.2017.04.001

Honěk A, Martinková Z, Štrobach J (2018) Effect of aphid abundance and urbanization on the abundance of Harmonia axyridis (Coleoptera: Coccinellidae). Eur J Entomol 115:703-707. https:// doi.org/10.14411/eje.2018.069

Junkiert Ł, Wieczorek K, Wojciechowski W (2011) Diagnostic characters of the species of the genus Periphyllus van der Hoeven, 1963 (Hemiptera, Aphidoidea: Chaitophorinae) recorded in Poland. Aphids Oth Hemipt Insects 17:5-19

Kirstová M, Pyszko P, Kočárek P (2019) Factors influencing microhabitat selection and food preference of tree-dwelling earwigs (Dermaptera) in a temperate floodplain forest. B Entomol Res 109: 1-8. https://doi.org/10.1017/S0007485318000147

Laliberte E, Legendre P (2010) A distance-based framework for measuring functional diversity from multiple traits. Ecology 91:299-305. https://doi.org/10.1890/08-2244.1

Langellotto GA, Denno RF (2004) Responses of invertebrate natural enemies to complex-structured habitats: a meta-analytical synthesis. Oecologia 139:1-10. https://doi.org/10.1007/s00442-004-1497-3

Lefebvre M, Franck P, Olivares J, Ricard JM, Mandrin JF, Lavigne C (2017) Spider predation on rosy apple aphid in conventional, organic and insecticide-free orchards and its impact on aphid populations. Biol Control 104:57-65. https://doi.org/10.1016/j.biocontrol.2016. 10.009

Leigh S, van Emden HF (2017) Population dynamics: cycles and patterns. In: Emden HF, Harrington R (eds) Aphids as crop pests. CAB International, Wallingford, pp 262-279

Lessard JP, Buddle CM (2005) The effects of urbanization on ant assemblages (Hymenoptera: Formicidae) associated with the Molson nature reserve, Quebec. Can Entomol 137:215-225. https://doi.org/10. 4039/n04-055 
Long LC, D'Amico V, Frank SD (2019) Urban forest fragments buffer trees from warming and pests. Sci Total Environ 658:1523-1530. https://doi.org/10.1016/j.scitotenv.2018.12.293

Lövei GL, Horváth R, Elek Z, Magura T (2019) Diversity and assemblage filtering in ground-dwelling spiders (Araneae) along an urbanisation gradient in Denmark. Urban Ecosyst 22:345-353. https://doi. org/10.1007/s11252-018-0819-x

Mader HJ, Schell C, Kornacker P (1990) Linear barriers to arthropod movements in the landscape. Biol Conserv 54:209-222. https:// doi.org/10.1016/0006-3207(90)90052-Q

Markó V, Jenser G, Kondorosy E, Ábrahám L, Balázs K (2013) Flowers for better pest control? The effects of apple orchard ground cover management on green apple aphids (Aphis spp.) (Hemiptera: Aphididae), their predators and the canopy insect community. Biocon Sci Tech 23:126-145. https://doi.org/10.1080/09583157. 2012.743972

McDonnell MJ, Pickett ST (1990) Ecosystem structure and function along urban-rural gradients: an unexploited opportunity for ecology. Ecology 71:1232-1237. https://doi.org/10.2307/1938259

McDonnell MJ, Hahs AK (2008) The use of gradient analysis studies in advancing our understanding of the ecology of urbanizing landscapes: current status and future directions. Landsc Ecol 23:11431155. https://doi.org/10.1007/s10980-008-9253-4

McIntyre NE (2000) Ecology of urban arthropods: a review and a call to action. Ann Entomol Soc Am 93:825-835. https://doi.org/10.1603/ 0013-8746(2000)093\%5b0825:EOUAAR\%5d2.0.CO;2

McKinney ML (2006) Urbanization as a major cause of biotic homogenization. Biol Conserv 127:247-260. https://doi.org/10.1016/j. biocon.2005.09.005

Meineke EK, Holmquist AJ, Wimp GM, Frank SD (2017) Changes in spider community composition are associated with urban temperature, not herbivore abundance. J Urban Ecol 3:1-8. https://doi.org/ 10.1093/jue/juw010

Merckx T, Van Dyck H (2019) Urbanization-driven homogenization is more pronounced and happens at wider spatial scales in nocturnal and mobile flying insects. Glob Ecol Biogeogr 28:1440-1455. https://doi.org/10.1111/geb.12969

Miñarro M, Fernández-Mata G, Medina P (2010) Role of ants in structuring the aphid community on apple. Ecol Entomol 35:206-215. https://doi.org/10.1111/j.1365-2311.2010.01173.x

Moerkens R, Leirs H, Peusens G, Gobin B (2010) Dispersal of single-and double-brood populations of the European earwig, Forficula auricularia: a mark-recapture experiment. Entomol Exp Appl 137: 19-27. https://doi.org/10.1111/j.1570-7458.2010.01031.x

Muderere T, Murwira A, Tagwireyi P (2018) An analysis of trends in urban landscape ecology research in spatial ecological literature between 1986 and 2016. Curr Landscape Ecol Rep 3:43-56. https:// doi.org/10.1007/s40823-018-0033-9

Mueller TF, Blommers LHM, Mols PJM (1988) Earwig (Forficula auricularia) predation on the woolly apple aphid, Eriosoma lanigerum. Entomol Exp Appl 47:145-152. https://doi.org/10. 1111/j.1570-7458.1988.tb01129.x

Nagy Cs, Cross JV, Markó V (2015) Can artificial nectaries outcompete aphids in ant-aphid mutualism? Applying artificial sugar sources for ants to support better biological control of rosy apple aphid, Dysaphis plantaginea Passerini in apple orchards. Crop Prot 77: 127-138. https://doi.org/10.1016/j.cropro.2015.07.015

Niemelä J, Kotze DJ (2009) Carabid beetle assemblages along urban to rural gradients: a review. Landscape Urban Plan 92:65-71. https:// doi.org/10.1016/j.landurbplan.2009.05.016

Oksanen J, Blanchet FG, Friendly M, Kindt R, Legendre P, McGinn D, Minchin PR, O'Hara RB, Simpson GL, Sólymos P, Stevens MHH, Szoecs E, Wagner H (2018) Vegan: community ecology package. R Package Version 2.5-3. https://cran.r-project.org/web/packages/ vegan/index.html
Pacheco R, Vasconcelos HL (2007) Invertebrate conservation in urban areas: ants in the Brazilian Cerrado. Landscape Urban Plan 81:193199. https://doi.org/10.1016/j.landurbplan.2006.11.004

Parsons SE, Frank SD (2019) Urban tree pests and natural enemies respond to habitat at different spatial scales. J Urban Ecol 5:1-15. https://doi.org/10.1093/jue/juz010

Piano E, De Wolf K, Bona F, Bonte D, Bowler DE, Isaia M, Lens L, Merckx T, Mertens D, van Kerckvoorde M, De Meester L, Hendrickx F (2017) Urbanization drives community shifts towards thermophilic and dispersive species at local and landscape scales. Glob Chang Biol 23:2554-2564. https://doi.org/10.1111/gcb.13606

Piñol J, Espadaler X, Canellas N, Pérez N (2009a) Effects of the concurrent exclusion of ants and earwigs on aphid abundance in an organic citrus grove. BioControl 54:515-527. https://doi.org/10.1007/ s10526-008-9203-8

Piñol J, Espadaler X, Pérez N, Beven K (2009b) Testing a new model of aphid abundance with sedentary and non-sedentary predators. Ecol Model 220:2469-2480. https://doi.org/10.1016/j.ecolmodel.2009. 06.031

Purkart A, Morawski M, Masłowski A, Depa $Ł$ (2019) Ant-mediated anholocyclic overwintering of Prociphilus fraxini (Hemiptera: Aphididae) in Central Europe. Entomol Fenn 30:179-185. https:// doi.org/10.33338/ef. 87175

Quantum GIS Development Team (2018) Quantum GIS geographic information system. Open Source Geospatial Foundation Project http://qgisosgeoorg Accessed 20 Dec 2018

R Core Team (2018) R: a language and environment for statistical computing. R Foundation for Statistical Computing, Vienna. ISBN 3900051-07-0. https://www.r-project.org/. Accessed 20 Dec 2018

Raupp MJ, Shrewsbury PM, Herms DA (2010) Ecology of herbivorous arthropods in urban landscapes. Annu Rev Entomol 55:19-38. https://doi.org/10.1146/annurev-ento-112408-085351

Ricotta C, Moretti M (2011) CWM and Rao's quadratic diversity: a unified framework for functional ecology. Oecologia 167:181188. https://doi.org/10.1007/s00442-011-1965-5

Rizwan AM, Dennis YCL, Liu C (2008) A review on the generation, determination and mitigation of urban Heat Island. J Environ Sci 20: 120-128. https://doi.org/10.1016/S1001-0742(08)60019-4

Rocha EA, Fellowes MD (2018) Does urbanization explain differences in interactions between an insect herbivore and its natural enemies and mutualists? Urban Ecosyst 21:405-417. https://doi.org/10.1007/ s11252-017-0727-5

Rocha EA, Fellowes MD (2020) Urbanisation alters ecological interactions: ant mutualists increase and specialist insect predators decrease on an urban gradient. Sci Rep 10:6406. https://doi.org/10.1038/ s41598-020-62422-Z

Rocha EA, Souza EN, Bleakley LA., Burley C, Mott JL, Rue-Glutting G, Fellowes MD (2018) Influence of urbanisation and garden plants on the diversity and abundance of aphids and their ladybird and hoverfly predators. Eur J of Entomol 115:140-149. https://doi.org/10. 14411/eje.2018.013

Roloff A, Korn S, Gillner S (2009) The climate-species-matrix to select tree species for urban habitats considering climate change. Urban For Urban Gree 8:295-308. https://doi.org/10.1016/j.ufug.2009.08. 002

Roy HE, Brown PM, Adriaens T et al (2016) The harlequin ladybird, Harmonia axyridis: global perspectives on invasion history and ecology. Biol Invasions 18:997-1044. https://doi.org/10.1007/ s10530-016-1077-6

Schüepp C, Uzman D, Herzog F, Entling MH (2014) Habitat isolation affects plant-herbivore-enemy interactions on cherry trees. Biol Control 71:56-64. https://doi.org/10.1016/j.biocontrol.2014.01.007

Seto KC, Güneralp B, Hutyra LR (2012) Global forecasts of urban expansion to 2030 and direct impacts on biodiversity and carbon pools. P Natl Acad Sci USA 109:16083-16088. https://doi.org/10.1073/ pnas.1211658109 
Shrewsbury PM, Raupp MJ (2006) Do top-down or bottom-up forces determine Stephanitis pyrioides abundance in urban landscapes? Ecol Appl 16:262-272. https://doi.org/10.1890/04-1347

Skinner GJ, Whittaker JB (1981) An experimental investigation of interrelationships between the wood-ant (Formica rufa) and some treecanopy herbivores. J Anim Ecol 50:313-326. https://doi.org/10. 2307/4047

Stutz S, Entling MH (2011) Effects of the landscape context on aphid-antpredator interactions on cherry trees. Biol Control 57:37-43. https:// doi.org/10.1016/j.biocontrol.2011.01.001

Turrini T, Sanders D, Knop E (2016) Effects of urbanization on direct and indirect interactions in a tri-trophic system. Ecol Appl 26:664-675. https://doi.org/10.1890/14-1787

Venables WN, Ripley BD (2002) Modern applied statistics with S, 4nd edn. Springer, New York
Vepsäläinen K, Ikonen H, Koivula MJ (2008) The structure of ant assemblages in an urban area of Helsinki, southern Finland. Ann Zool Fenn 45:109-127. https://doi.org/10.5735/086.045.0203

Wachmann E, Melber A, Deckert J (2004-2012) Wanzen Band 1-5. Goecke \& Evers, Keltern

Welch KD, Harwood JD (2014) Temporal dynamics of natural enemypest interactions in a changing environment. Biol Control 75:18-27. https://doi.org/10.1016/j.biocontrol.2014.01.004

Wyss E, Niggli U, Nentwig W (1995) The impact of spiders on aphid populations in a strip-managed apple orchard. J Appl Entomol 119: 473-478. https://doi.org/10.1111/j.1439-0418.1995.tb01320.x

Zuur AF, Ieno EN, Walker NJ, Saveliev AA, Smith GM (2009) Mixed effects models and extensions in ecology with R. Springer, New York 